\title{
Socioeconomic Rights and Theories of Justice
}

\author{
JEREMY WALDRON*
}

\section{TABLE OF CONTENTS}

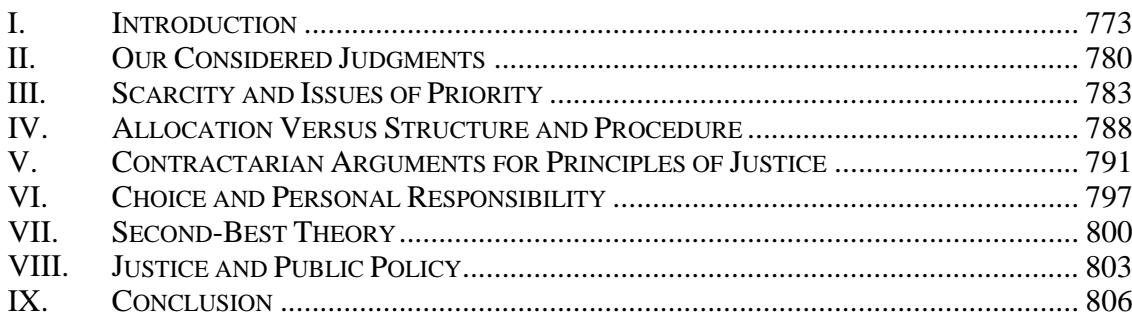

\section{INTRODUCTION}

What is the relation between socioeconomic rights and theories of justice? By socioeconomic rights, I mean rights of the kind we see listed in Articles 23-26 of the Universal Declaration of Human Rights (UDHR), ${ }^{1}$ in Articles 9-13 of the International Covenant on Economic,

* University Professor and Professor of Law, New York University, and Chichele Professor of Social and Political Theory, Oxford. I am grateful to Ronald Dworkin, John Ferejohn, Bernard Grofman, Jeff Howard, Janos Kis, Liora Lazarus, Franch Michelman, Dan McDermott, David Miller, Thomas Nagel, Pasquale Pasquino, Thomas Pogge, and Henry Shue for comments on an earlier draft of this Article. Portions of pages 784-87 are reprinted with the permission of the Cambridge University Press.

1. Universal Declaration of Human Rights, G.A. Res. 217 (III) A, U.N. Doc. A/RES/217(III), at 75-76 (Dec. 10, 1948) (declaring, for example, rights to education, to an adequate standard of living, and to protection against unemployment). 
Social and Cultural Rights (ICESCR), ${ }^{2}$ and in national instruments such as Articles 26-29 of the South African Constitution's Bill of Rights. ${ }^{3}$ Now the articles just mentioned are legal or quasi-legal provisions. I really want to ask about the principles they embody or seek to embody. What is the relation between something like the principle that everyone has a right to social assistance if they are unable to support themselves and the principles typically comprised in a theory of justice?

By a theory of justice, I mean something that does the sort of thing that John Rawls did in his book A Theory of Justice ${ }^{4}$ : set out and defend some very general principles governing the basic structure of society in regard to their impact on the life prospects of and the enjoyment of primary goods by individuals. I do not by any means regard Rawls's work as canonical. Later in the Article, I shall refer to two alternative theories, at least one of them quite stridently opposed to Rawls's. But Rawls's work affords a fine example of the sort of thing I mean by a theory of justice, and it makes clear the difficulty of the question I want to ask. Rawls's theory is certainly not hostile to the idea of welfare provision, but principles of the kind alluded to in the previous paragraph do not feature among Rawls's principles of justice as fairness-among the two complex principles that constitute his conception of justice. ${ }^{5}$ Why is this? The most plausible explanation is that socioeconomic rights, or principles embodying socioeconomic rights, are usually formulated at the wrong level of generality or abstraction to be included among the most fundamental principles of a theory such as Rawls's. But then we should ask, What is the relationship between abstract principles of justice and these somewhat less abstract principles requiring welfare provision?

For the purpose of answering this question, Rawls's theory has the advantage of being quite complicated in the set of abstract principles that it yields, in its internal structure, and in the system of argumentation associated with it. His theory is built up on the basis of certain-by now familiar-model-theoretic ideas, such as the original position ${ }^{6}$ and the veil of ignorance. ${ }^{7}$ It comprises a number of meta-ethical conceptions about reflective equilibrium and the relation of a philosophical construction

2. International Covenant on Economic, Social and Cultural Rights, G.A. Res. 2200 (XXI) A, Annex, U.N. Doc. A/6316, at 50-51 (Dec. 16, 1966) (declaring, for example, rights to social security, to special protections for mothers and children, and to freedom from hunger).

3. S. AFR. CONST., 1996, arts. 26-29 (declaring, for example, rights of access to adequate housing and health care services).

4. See John Rawls, A Theory of Justice 52-78 (rev. ed. 1999).

5. Id. at 52-56.

6. Id. at 181 .

7. Id. at 130-60. 
to commonsense precepts and our considered judgments about justice. ${ }^{8}$ It includes an account of the relation between justice and the theory of the person. In the elaboration of the theory's practical implications, there is the "four-stage sequence," there are theories of institutional competence and institutional responsibility, there is an argument about the pure procedural characteristics of what Rawls calls the basic structure, and there is a complex account of the relation between the two principles of justice as fairness and certain detailed theorems in public policy. ${ }^{9}$ All of this makes Rawls's theory a good paradigm for our purposes. As I said, this is not because it is the last word on justice. Rather, it is because the theory offers numerous possible points of access for argument about socioeconomic rights, making it interesting to consider where in this complex structure such arguments are most appropriately located.

I think this consideration can be very helpful in political philosophy. Here is one way it can help: Some well-known theories of justice give the impression of being hostile to socioeconomic rights. Robert Nozick's theory of historical entitlement in Anarchy, State, and Utopia is a good example. ${ }^{10}$ If we want to figure out what to think about this hostilitywhether it is justified or whether it can be answered-we also have to ask, What is the proper relation between socioeconomic rights and a theory of justice? Only then can we assess whether a convincing case has been made by the theorist in question for denying that there is any justification for socioeconomic rights.

You might think that it is unnecessary to confront questions like these or that confronting them is a purely academic exercise. If we are independently convinced that a case can be made for principles like those embodied in UDHR Article $23(1)^{11}$ or ICESCR Article 11(1), ${ }^{12}$ why should we care how that relates to a highly abstract theory like John Rawls's or to a conception of justice founded on principles known to be

8. See infra Part II.

9. See infra Part VIII.

10. See Robert Nozick, ANARchy, StATE, And Utopia 238 (1974); Jeremy Waldron, Nozick and Locke: Filling the Space of Rights, 22 Soc. PHIL. \& POL'y 81, 110 (2005).

11. G.A. Res. 217 (III) A, supra note 1, at 75 (“"[T]he right to work, to free choice of employment, to just and favourable conditions of work and to protection against unemployment.”).

12. G.A. Res. 2200 (XXI) A, supra note 2, at 50 (“[T]he right of everyone to an adequate standard of living for himself and his family, including adequate food, clothing and housing, and to the continuous improvement of living conditions.”). 
hostile to socioeconomic rights like that of Robert Nozick's? Moral philosophers may be preoccupied with the delicacies of Nozick's or Rawls's model-theoretic conceptions. But these conceptions are so remote in their abstraction from the compelling matters that proponents of socioeconomic rights have to address-life and death, sickness and health, poverty and human flourishing - that they are best left to languish in their ivory towers where they will not distract us from the more urgent concerns of human well-being.

I think saying that would be a mistake. The structural relation between socioeconomic rights and theories of justice is certainly a fascinating intellectual conundrum. But it is of more than academic interest. The claim that there are socioeconomic rights, that they really are human rights, that they deserve to be taken as seriously as, say, civil and political rights, and that the failure to fulfill them is in the same normative category as rights violations like torture, censorship, disenfranchisement, or detention without trial is controversial even on its own ground. Politically it is attacked by those who claim priority for property rights and market structures, by those who deplore the way in which welfare provision privileges the lazy and the feckless over the responsible and the deserving, as well as by those who simply believe in other fiscal or macroeconomic priorities in what they say is a world of limited resources. These attacks cannot be dismissed; they require-and in my view, they can be given-an answer. But they are not adequately answered just by saying that the case for welfare provision is urgent and should command a very high place in the order of moral priorities. Even if one can defend the claim that socioeconomic rights are important, the nature of their priority over other concerns is not self-evident. There are all sorts of priorities in this area of moral and political life, and we need to develop an articulate account of what kind of priority we are talking about.

For example, nobody these days seriously imagines an economy, either at the national level or at the international level, in which private property and markets do not loom large, or in which the question of incentives for and rewards to the deserving are not thought important, or in which there is not a multitude of other claims on the public purse- or a host of other macroeconomic concerns-competing with demands for welfare provision. Though these considerations obviously compete with claims about socioeconomic rights, they are not to be dismissed simply on account of their being inimical to the latter claims. They need to be given their due in an overall account of what the organization of the basic structure of a society, national or international, ought to respond to. Formulating such an account, articulating and elaborating it, is precisely the task of a theory of justice. 
Of course, existing philosophical defenses of socioeconomic rights already do a fair bit of this. ${ }^{13}$ They defend such rights against some of the more obvious criticisms, and they seek either to discredit property, desert, and other fiscal priorities or to show that these are much less important than they claim to be. It is not hard to make a rhetorically convincing case along these lines, precisely because socioeconomic rights purport to address the claims of direst need directly and vividly-and often as a last resort - whereas the importance of these other competing claims-about property, markets, desert, and fiscal and macroeconomic concerns-is presented a little further back from the margins of life and death. Or to put it more crudely: it is easy for defenders of socioeconomic rights to make their opponents sound heartless. But just that advantage should put us on warning that it might be worth exploring the competition between these various sorts of claims from other angles too, if only as a sort of reality check to ensure that our use of the rhetoric of dire need is not just a way of browbeating our opponents, bullying the moderates, and intoxicating ourselves with our own righteousness.

On the other hand, I do not want to leave the impression that the disparity between the tone and rhetoric of argument for socioeconomic rights - intense, concrete, and passionately concerned — and the tone and rhetoric of argument for theories of justice-dry, detached, abstract, and impossibly elaborate-is just a matter of personal style as between, say, welfare advocates and philosophers. I certainly do not mean to suggest that defenders of socioeconomic rights cheat on their arguments or sell short the sort of fundamental values, like respect for persons, human dignity, autonomy, and basic equality, that ought to anchor our views about justice. On the contrary, defenders of socioeconomic rights are second to none in their taking these fundamental premises seriously and in their determination to bring out the practical implications that they really have for the concrete predicament of impoverished men, women, and children in the world. They rightly convey that arguing from premises like these cannot be regarded as a game or as a mere academic exercise.

The disparity that interests me is not so much in the premises that are used but in the conclusions that the respective bodies of argument are aiming at. Although defenders of socioeconomic rights are interested in

13. See, e.g., David Copp, The Right to an Adequate Standard of Living: Justice, Autonomy, and the Basic Needs, in Economic RighTs 231, 232-34 (Ellen Frankel Paul et al. eds., 1992). 
arguing from fundamental premises for something quite specific, such as health care, social security, or minimum income, in a sort of line-item way, proponents of a theory of justice are arguing from fundamental premises for principles, such as the "Difference Principle,"14 that are intended to operate at a much more general level. What I am urging when I say that it would be a good idea to bring these bodies of argument into some careful relation with one another is that we need to get a better sense of how the line-item claims that we call socioeconomic rights fit into a bigger picture that takes these fundamental values as seriously as the proponents of socioeconomic rights take them.

I emphasize that last point. The aim of this Article is not to haul socioeconomic rights before some tribunal of efficiency or aggregate utility. Critics who regard efficiency or aggregate utility as the be-all and end-all of public policy have already committed serious mistakes: they have an impoverished conception of value, and they pursue the values that they recognize in an inappropriate way by concentrating on arithmetical aggregates rather than on individualized or distributive concerns. Theorists of justice avoid mistakes like these. They may not agree with one another about the proper conception of value for public policy — welfare, primary goods, human capacities, et cetera-or what exactly the distributive structure of an appropriate theory ought to be. But they are committed to evaluating social policy in terms that take individuals seriously and that have the capacity to take the special concerns of poor people seriously. The game is not rigged against the distributive concerns of the theorist of socioeconomic rights like it is in the economic critique. One could say that to ask about the proper relation between a theory of social-economic rights and a theory of justice is to ask a fair-as opposed to an unfair-question.

Benefits, I believe, will accrue to both sides if theories of socioeconomic rights are brought together with theories of justice. Theories of justice sometimes tend to consign their consideration of specific lines of public policy to an afterthought, tacked onto the main structure and argued for half-heartedly and often superficially. This is certainly true of the comments that Rawls makes about welfare provision and what he calls "the social minimum."15 A clearer sense, within a theory of justice, of how particular public policy commitments could rise to the status of rights would improve matters. Such consideration would fully take into account the need to consider the public policy line in question in relation to other competing claims and commitments, but it would also be looking to justify it, in this context, as a right-as something that would

14. See RAWLS, supra note 4 , at $65-73$.

15. See id. at 244-45. 
have standing in public policy as a matter of principle, not just as a contingent and variable output of the theory.

Equally, from the point of view of the proponents of socioeconomic rights, I believe that pursuing the argument about these rights under the auspices of a theory of justice may enable us to make a better case for them than arguing directly in the way their proponents currently do. This is for the reason already mentioned: a theory of justice necessarily brings together with the consideration of socioeconomic rights a consideration of all the claims and principles with which such rights might be thought to compete or conflict. If the resources that socioeconomic rights require are scarce, relative to these and other requirements, then it is to a theory of justice that we must look for allocation under scarcity. Or if the resources that socioeconomic rights require are privately owned or subject in some other way to others' claims, on the basis, for example, of labor, desert, or wealth creation, then we need more than a theory of socioeconomic rights to show that they should nevertheless be made available for welfare provision; we need a theory of justice to provide a general matrix for considering and reconciling these competing claims. The general point here is that theories of rights do good work when it comes to explaining why each right is important, but they are notoriously bad at thinking about conflict or competition among rights or among claims that aspire to be treated as rights. ${ }^{16}$ Theories of justice may be a little too abstract for the taste of those who are used to line-item consideration of some quite concretely specified rights, but their raison d'être is the consideration of competing claims and interests in a distributive context in which it is understood that not everyone can get what they want or even what we ideally would like to secure for them. It is surely appropriate, then, to bring this second perspective to bear on the first.

If it is known that the case for a right like that in ICESCR Article $11(1)^{17}$ has been made without proper consideration of competing claims, then the alleged right is easy to discredit, easy to dismiss as naïve, and unrealistic. If, however, the alleged socioeconomic right has been properly defended in the context of a theory of justice, then it may

16. For a sampling of the sparse literature on conflicts of rights, see Jeremy Waldron, Rights in Conflict, 99 EтHICs 503, 503-06 (1989), and F.M. Kamm, Conflicts of Rights: Typology, Methodology, and Nonconsequentialism, 7 LEGAL THEORY 239, 242-51 (2001).

17. G.A. Res. 2200 (XXI) A, supra note 2, at 50-51. 
be presented more confidently and more effectively in political and philosophical argument. Its presentation can be associated with a sense that competing claims - to property, desert, or whatever — have had a fair chance of consideration in a way that takes their normative aspirations seriously. And this way of defending it will also be a way of illustrating and driving home the point that when claims of right are in the air, recourse to a utilitarian or economic matrix is not always appropriate.

What follows is not a comprehensive survey. It is certainly not a comprehensive survey of theories of justice. Rawls's theory will often serve as an illustration, though in some places I will also consider Robert Nozick's theory of historical entitlement. The aim, however, is not to oppose these theories to one another but rather to get a taste of the variety of ways in which claims about socioeconomic rights may figure into a broader theoretical conception. Also, I will not offer an exhaustive review of the ways in which socioeconomic rights might be related to or emerge from a complex theory of justice. I have chosen seven main areas to focus on: (1) the role of considered judgments about welfare and the relief of poverty in the formation of a theory of justice, (2) the importance of scarcity and issues of priority in defining the agenda for justice and the constraints facing the proponents of any costly right, (3) the difference between allocative and structural/procedural approaches to justice, (4) the use of contractarian ideas to argue for particular principles of justice, (5) the importance that a theory of justice will attach to choice and personal responsibility, (6) the relation between first-best and second-best accounts, and (7) the relation between the more abstract and the more policy-oriented aspects of a theory of justice. Other facets of the relationship are no doubt worth examining too, but the ones I have listed will be enough to begin with. This Article is just a start; I hope it affords a basis for others to build on.

\section{OUR CONSIDERED JUDGMENTS}

Our theories of justice are motivated, driven, and to a certain extent constrained by what we sometimes call our intuitions about justice, but which might more accurately be described as our considered but on-thewhole pretheoretical judgments about some of the matters that justice deals with. Whether or not one adopts Rawls's methodology of reflective equilibrium, ${ }^{18}$ these considered judgments play an important role both in specifying what it is that we want to think about and also in fixing our sense of what we expect our theory of justice to validate or make sense of. They may also provide reality checks at various stages of our

18. See RAWLS, supra note 4 , at $40-46$. 
argumentation about justice; we may find a given theoretical position plausible or implausible-intuitively plausible or implausible as we say-because of its consonance or dissonance with one or more of these considered judgments.

These judgments need not be just the sentiments of private individuals. They may have the status among us of "precepts of justice"-commonsense truths shared to a certain extent in the culture even among philosophers. ${ }^{19}$ There is no doubt that claims about socioeconomic rights are supported by many of these judgments and precepts. Many of us believe, for example, that if a child is in danger of starvation in a society with a prosperous economy and if the child's parents are incapable of supporting it, then there ought to be some provision for social support and that staterun agencies have a responsibility to see that this is provided. Many of us would regard it as a serious objection to a theory of justice if it implied that this need not be done or that it should not be done. ${ }^{20}$

Of course, nobody's considered judgments are self-validating. For one thing, considered judgments about provision for need may have to be reconciled with other considered judgments of ours that seem to pull in an opposite direction. Many people hold the view, pretheoretically, that individuals are entitled to the fruits of their labor-such as the income that others have paid them for work they have done-and they

19. See id. at 31-32.

20. A lot of the early hostility to Robert Nozick's theory stemmed from the fact that Nozick gave the impression that such provision might be unjust or at any rate not required by justice. People thought that if Nozick's was just one theory competing for our attention, this might be a reason to look elsewhere for theoretical illumination on the topic of justice. See Brian Barry, Book Review, 3 Pol. Theory 331, 331-32 (1975) (reviewing NozICK, supra note 10).

[T] he intellectual texture is of a sort of cuteness that would be wearing in a graduate student and seems to me quite indecent in someone who, from the lofty heights of a professorial chair, is proposing to starve or humiliate ten percent or so of his fellow citizens (if he recognizes the word) by eliminating all transfer payments through the state, leaving the sick, the old, the disabled, the mothers with young children and no breadwinner, and so on, to the tender mercies of private charity, given at the whim and pleasure of the donors and on any terms that they choose to impose.

This is, no doubt, an emotional response, but there are, I believe, occasions when an emotional response is the only intellectually honest one. ... [A] book whose argument would entail the repeal of even the Elizabethan Poor Law must either be regarded as a huge joke or as a case of trahison des clercs, giving spurious intellectual respectability to the reactionary backlash that is Id. already visible in other ways in the United States. 
believe that it would count against a theory of justice if that theory were to hold that their income were simply to be made available against their will for the satisfying of other people's needs. These two judgments may not directly contradict one another, but they are in tension, and the task of a theory of justice is to reconcile whatever is important in one with whatever is important in the other, in the context of their application to thousands or millions of individuals in a society or in the world. If this is true, then we should not expect either judgment to survive its consideration in a theory of justice in an unmodified form. Our considered judgments are like inputs into the theory, but the outputs may look somewhat different. Of course that is not inevitable; maybe one or another judgment will emerge largely intact. But a theory of justice offers no guarantees in this regard, and this may be important for how we think about socioeconomic rights. Inasmuch as the case for them is largely intuitive or based simply on the fact that they embody one set of strong convictions that we hold, then we have to be open to the possibility that they will not survive in the form that a simple rights slogan expresses when they emerge from serious consideration under the auspices of a theory of justice.

Also, a theory of justice may sometimes be radical or quite revisionary as far as our considered judgments are concerned. People sometimes approach the topic of justice with a pretheoretical conviction that individuals deserve certain things-for example, that hard-working and prudent people deserve the wealth that they have created on the basis of the moral merit evinced in their abstemious industriousness. (This too is sometimes put forward as being in tension with the "intuitions" embodied in claims about socioeconomic rights.) But in A Theory of Justice, John Rawls criticizes such claims. He does not just strike a different balance between the claims of need and the claims of desert; he argues that the latter claims are mostly misconceived. ${ }^{21}$ He may or may not be right about that. The point is that a theory of justice cannot promise immunity in advance against such revision to any set of intuitions. $^{22}$

The role of considered judgments and precepts helps us understand the complexity of the relation between rights and justice. On the one hand, our convictions about rights often present themselves to us as obvious, in a way that does not require much philosophical elaboration: "We hold

21. See RAWLS, supra note 4 , at 88-89.

22. See Liam Murphy \& ThOMAs NAgel, The Myth of OwNERship: TAXes AND JUSTICE 173 (2002) (arguing that individuals are not really morally entitled to pretax income). 
these truths to be self evident., ${ }^{23}$ But theoretical work on justice gets underway when it becomes apparent that not all of the things that appear self-evident (one by one) to a person or to the members of a group of people or to a whole society or civilization can be held together, at least in unadulterated form. This fact has convinced some people that the language of rights is inappropriate for political discourse: "It is from the beginning to the end so much flat assertion .... It lays down as a fundamental and inviolable principle whatever is in dispute.... The strength of this argument is in proportion to the strength of lungs in those who use it." ${ }^{24}$ But that is too extreme a reaction. Intuitive convictions about rights play a healthy role in stimulating theories of justice, and as we shall see, some of the conclusions of theorizing about justice are properly presented in the language of rights.

\section{SCARCITY AND ISSUES OF PRIORITY}

Some critics argue that even considered as commonsense precepts, claims about socioeconomic rights have to be rejected because they violate the logical principle that ought implies can. ${ }^{25}$ Many states, say these critics, do not have the resources to provide even minimal economic security for masses of their citizens, and because states differ considerably in this regard, it hardly makes sense to regard economic provision as a matter of universal human entitlement. ${ }^{26}$ A theory of justice will make this difficulty —if it is a difficulty — apparent at an early stage because its entire apparatus is predicated upon a presupposition of scarcity: like the limited altruism of human beings, the scarcity of material resources is a fact of life and a basic circumstance of all our talk about justice. ${ }^{27}$

But the argument is too quick. It is true that the resources and services that socioeconomic rights need to draw upon are scarce relative to the whole set of demands that are placed upon them. But what this indicates is that there needs to be some sorting, balancing, and prioritization among these demands. It does not follow that one subset of the demands

23. THE DECLARATION OF INDEPENDENCE para. 2 (U.S. 1776).

24. Jeremy Bentham, Anarchical Fallacies, in NONSENSE UPON STILTS: BENTHAM, BURKE AND MARX ON THE RigHTS OF MAN 46, 74 (Jeremy Waldron ed., 1987).

25. See Waldron, supra note 16 , at 506.

26. See, e.g., Maurice Cranston, Human Rights, Real and Supposed, in PolitiCAL THEORY AND THE RigHTS OF MAN 43, 50-51 (D.D. Raphael ed., 1967).

27. See RAwLs, supra note 4, at 109-12; see also DAVID Hume, A TrEatise of HumAn NATURE 494-95 (L.A. Selby-Bigge \& P. H. Nidditch eds., 1978). 
(socioeconomic rights) must be abandoned as impossible. There is no reason to suppose that there are not enough resources in the world, say, to feed, house, or provide basic medical care to everybody in it, as Articles 11 and 12 of ICESCR require. ${ }^{28}$ The difficulty is that there are also other demands on these resources - other fiscal priorities and other uses that individuals and firms might have for the income and wealth that would have to be taxed or otherwise accessed if fiscal capacity were to be increased. If it did follow from scarcity in this sense that we should abandon some subset of the demands that are placed upon scarce resources, then we would need to hear arguments back and forth about which subset of demands this should be. For example, weapons and military demands compete fiscally with demands for socioeconomic provision. Why not abandon the former rather than the latter? I do not mean this as a rhetorical question. I mean to ask for an answer and to ask also for the hard work-including hard work in our theory of justice - that would be necessary to explain and defend a given answer.

These points are particularly important when it comes to thinking about the relation between socioeconomic claims and property rights. The alleged impossibility of socioeconomic claims - the difficulty with the idea that ought implies can-is often based on an assumption that the existing distribution of property is to remain largely undisturbed. When a conservative government in the West says, for example, in response to some plea for welfare provision, “The money simply isn't there," what is usually meant is that it would be impolitic to try and raise it from existing income earners by taxation. But if resources are scarce relative to human wants, any system of rights or entitlements will seem demanding to those who are constrained by it. If an economic system includes provision for welfare assistance, that may seem overly demanding to taxpayers. But if it does not include that provision, then the system of property rights in such an economy will seem overly demanding to the poor, requiring as it does that they refrain from making use of resources that they need in order to survive. As usual, the question is not whether we are to have a system of demanding rights but how the costs of the demands are to be distributed.

Robert Nozick may be guilty of a fallacy along these lines when he voices the following general misgiving about socioeconomic rights ${ }^{29}$ :

The major objection to speaking of everyone's having a right to various things such as equality of opportunity, life, and so on, and enforcing this right is that these "rights" require a substructure of things and materials and actions; and other people may have rights and entitlements over these. No

28. See G.A. Res. 2200 (XXI) A, supra note 2, at 50-52.

29. The remainder of this Part is adapted from Waldron, supra note 10. 
one has a right to something whose realization requires certain uses of things and activities that other people have rights and entitlements over. Other people's rights and entitlements to particular things (that pencil, their body, and so on) and how they choose to exercise these rights and entitlements fix the external environment of any given individual and the means that will be available to him. ...

There are particular rights over particular things held by particular persons, and particular rights to reach agreements with others, if you and they together can acquire the means to reach an agreement.... No rights exist in conflict with this substructure of particular rights. Since no neatly contoured [socioeconomic] right ... will avoid incompatibility with this substructure, no such rights exist. The particular rights over things fill the space of rights, leaving no room for general rights to be in a certain material condition. The reverse theory would place only such universally held general "rights to" achieve goals or to be in a certain material condition into its substructure so as to determine all else; to my knowledge no serious attempt has been made to state this "reverse" theory. ${ }^{30}$

Nozick's argument here assumes that claims based on need occupy a relatively superficial role in a general theory of economic entitlement. It is as though we first figure out who owns what, applying the principles that determine property rights, and then figure out whose needs are left unsatisfied and what is to be done about them. On this approach, socioeconomic rights - if there are any-live only in the interstices of property. Some of what Nozick says suggests that this subordination of welfare to property is more or less unavoidable: "Things come into the world already attached to people having entitlements over them." $31 \mathrm{He}$ thinks this is clearest in the case of body parts: you may need these kidneys or this retina, but my entitlement to them is necessarily prior to yours for we cannot even grasp my status as a person without comprising in that status a rightful claim to the limbs, cells, and organs that make me who I am. ${ }^{32}$ He thinks it holds for some external objects as well, appealing to the intuition we cited earlier: "Isn't it implausible that how holdings are produced and come to exist has no effect at all on who should hold what?"33 The trouble with socioeconomic rights, on this account, is that they "treat objects as if they appeared from nowhere, out of nothing.

Nozick's position is that "particular rights over things fill the space of rights, leaving no room for general rights to be in a certain material

30. NozicK, supra note 10, at 238.

31. Id. at 160 .

32. Id. at 206.

33. Id. at 155 .

34. Id. at 160 . 
condition.” ${ }^{35}$ He maintains that the alternative is to stipulate the socioeconomic rights first and then try to fit property entitlements around them, and he says in the long passage I quoted that no serious attempt has been made to state this reverse theory. ${ }^{36}$ In fact, Nozick's own view has certain features that involve exactly the alternative structure he is referring to here. Nozick, like John Locke before him, believes that the initial acquisition of property rights must not be conducted in a way that is indifferent to the predicament of needy individuals who might be constrained by the rights in question. Nozick is committed to the following proposition, as a proviso qualifying his account of the acquisition of property:

A process normally giving rise to a permanent bequeathable property right in a previously unowned thing will not do so if the position of others no longer at liberty to use the thing is thereby worsened. ${ }^{37}$

What is this, if it is not a statement of what Nozick called the reverse theory? It gives priority to the right not to have one's material situation worsened, whether that situation consists in holding property rights or just in having access of some kind to the resources needed for a decent life. It gives these rights priority in exactly the sense that the reverse theory is supposed to give priority to socioeconomic rights: property entitlements must work around them, and no such entitlements are recognized if they are incompatible with these rights.

Nor is this an inadvertent slip on Nozick's part. Almost all philosophical defenders of private property acknowledge the need to develop principles for the acquisition and use of property that respect each person's fundamental right to derive sustenance from this world

35. Id. at 238.

36. Id. In fact some philosophers have toyed with versions of such a reverse approach. In Property Rights and Interests, Virginia Held compared acquisitive economic activity to a game, "where winners and losers compete on friendly terms as if engaged in a sporting event." Virginia Held, Property Rights and Interests, 46 Soc. REs. 550, 577 (1979). The idea was that winners are allowed to keep their winnings and "losers may prefer having had a chance to play the game, and especially having a chance to play again and win, than to ... be assured all along of an even apportionment of all proceeds." Id. But Held did not think that this game-playing could trump socioeconomic rights:

Economic justice is a serious matter. While those with moral rights to decent lives are deprived of these rights, playing games is not only frivolous but immoral. However, if such rights were respected ... and if, on utilitarian grounds, playing economic games could be justified in terms of the maximization of interests, well then there might be nothing wrong with capitalist games Id. at 579 .

between consenting gamblers .... . But first, the children ought to be fed.

37. NozICK, supra note 10, at 178. 
that is our common heritage. ${ }^{38}$ Few are willing to say that property rights are justified utterly without reference to the interests or needs of those whom they exclude from access to resources. The reason is obvious: to justify a property right in $X$ is not only to feel justified in oneself's coercively excluding others from $X$ but to justify other people's recognition of a duty to refrain from using $X$ even when one is not around oneself to physically defend it.

My reason for including this lengthy consideration of Nozick's proviso is to help us see that a theory of justice may take on board compelling principles about human need in ways that are unfamiliar or disconcerting. We were expecting to see them surface as freestanding rights, yet here they surface as conditions or provisos on principles of historic entitlement. Someone may claim, of course, that although Nozick's proviso does represent $a$ way of acknowledging the sort of needs that are also acknowledged in claims of socioeconomic rights, it is not an adequate way of acknowledging the force of such considerations. But that will have to be argued. We are not proceeding with any guarantee that the form in which welfare considerations emerge in a theory of justice exactly matches the form in which they present themselves in our considered judgments, in our commonsense precepts, or for that matter in some legal or internal formulations.

Certainly, Nozick's way of thinking about the relation between the claims of need and claims related to property in the context of a theory of justice is not the only way we can think about this. In Part V, I shall consider the quite different way Rawls deals with these matters in chapter 5 of $A$ Theory of Justice. ${ }^{39}$ Rawls's approach is probably more congenial to defenders of socioeconomic rights than Nozick's. But I have to say again: we are not entitled to take the emergence of a familiar-looking socioeconomic right as a criterion of adequacy for a theory of justice. Adequacy means that the relevant claims have been given proper consideration, not that the conclusion coincides with the views we began with.

38. For a survey, see Thomas A. Horne, Property Rights and Poverty: Political ARgument In BRITAIN (1990). John Locke, for example, recognizes it by allowing a right of recourse to all property in the last resort for the needy. See JoHN Locke, Two Treatises of Government 205-06 (Peter Laslett ed., Cambridge Univ. Press 1960) (1690).

39. See infra Part V. 


\section{Allocation Versus Structure AND PROCEDURE}

One might think about the relation between a theory of justice and socioeconomic rights in the following way:

Distributive justice involves choosing criteria for the distribution of something valuable, such as money or other goods, among people who have some claim upon a common stock or a common fund. These criteria are embodied in principles. One possible allocative principle is $P_{n}$ : "To each according to one's needs." So a belief in socioeconomic rights is a belief that something like this distributive principle should be one of the outputs that a theory of justice comes up with, and that it should be applied to the resources that society has at its disposal. Of course there are other candidates; for example, $P_{d}$, "To each according to one's desert," is an alternative principle that is often heard. To think that there are socioeconomic rights, therefore, is to think that theorizing about distributive justice will show that $P_{n}$ is a correct principle, at least over some important range of needs, and that $P_{d}$ is not a correct principle to the extent that it is incompatible with $P_{n}$.

Theories of distributive justice that aspire to yield principles like $P_{n}$ or $P_{d}$ are sometimes called allocative theories. Allocative theories have a venerable history in the discussion of justice: they have a prominent place in Aristotle's discussion of distributive justice, particularly in his discussion of the proper distribution of political power in The Politics. ${ }^{40}$ But most modern theorists of justice reject the allocative approach or at best confine it to a very special range of cases where there is a common stock of resources on which a number of identifiable individuals have undoubted-but so far unquantified — claims. The division of matrimonial assets upon divorce might be an example.

Robert Nozick's theory is adamantly opposed to the allocative approach. The reason is straightforward: allocation treats goods as though they were simply there, awaiting distribution, as though the process by which they were produced had no relevance. It is part of his rejection of what he calls patterned principles-principles that try to pattern the distribution of goods on something else like need or desert:

Isn't it implausible that how holdings are produced and come to exist has no effect at all on who should hold what?

....

To think that the task of a theory of distributive justice is to fill in the blank in "to each according to his " is to be predisposed to search for a pattern; and the separate treatment of "from each according to his __ treats production and distribution as two separate and independent issues. On an entitlement view these are not two separate questions. ${ }^{41}$

40. See Aristotle, Nicomachean Ethics 113, 116-18 (Martin Ostwald trans., Bobbs-Merrill Co. 1962); ARISTOTLe, The Politics, reprinted in The Politics AND The CONSTITUTION OF ATHENS 9, 63, 67, 71, 78-79 (Stephen Everson ed., 1996).

41. NozICK, supra note 10, at 155, 159-60. 
Nozick's own substantive position is that "[w]hoever makes something . . . is entitled to it." $" 2$ But we need not accept this in order to accept his critique of the allocative approach. His view is one way of linking productive and distributive issues together; there may be others. The more abstract point is that they ought to be linked and that justice ought to deal with both of them together. We need principles of justice to apply not to distribution considered apart from production or vice versa but to the structure of production enmeshed with distribution that we are likely to see in a real working economy.

The holistic emphasis on structure, as opposed to distributive questions posed in isolation, is typical of Rawls's approach as well. Rawls too is anxious that the task of a theory of justice not be understood simply as an allocation of distributive shares: who gets what when and how? "We must not assume," he says, "that there is much similarity from the standpoint of justice between an administrative allotment of goods to specific persons and the appropriate design of society." ${ }^{3}$ He also says that "[i]f it is asked in the abstract whether one distribution of a given stock of things to definite individuals ... is better than another, then there is simply no answer to this question." 44 Thus, for example, Rawls's Difference Principle is not to be interpreted as dictating that the worstoff group be given a certain share of resources. ${ }^{45}$ Instead, the effect of the principle is that when we are designing or, more likely, evaluating and reforming the network of rules and procedures that constitute the institutional structure of society, we should do so in a way that is oriented towards the advantage of the worst-off group. The institutions should be designed to operate on the assumption that when the system is working, outcomes are evaluated purely procedurally. We are not to meddle with the outcomes of a just institutional structure even if we think that by

42. Id. at 160 .

43. RAWLS, supra note 4 , at 56.

44. Id. at 76

45. The Difference Principle certainly reveals a spirit congenial to something like welfare provision inasmuch as it requires particular attention to the plight of the worstoff members of society. On the other hand, it also suggests that it is possible to justify great inequalities, which on some accounts it is the task of socioeconomic rights to mitigate. In general, the Difference Principle is too abstract to generate, by itself, any particular case for welfare provision. It is a principle governing the most abstract distributive implications of the basic structure, and it deals with them holistically, without regard to particular institutional arrangements or sources of advantage or disadvantage. If the Difference Principle provides the basis of a case for socioeconomic rights, it does so in the context of its detailed elaboration. 
doing so we could make the array of outcomes even more just from a distributive point of view.

In a book on social justice published in the mid-1970s, F.A. Hayek took these comments by Rawls to indicate that the difference between Rawls's approach and his own approach is "more verbal than substantial."46 Rawls's work, he says, has been "wrongly ... interpreted as lending support to socialist demands." 47 He takes Rawls to agree with his own central claim that "[j]ustice is not concerned with those unintended consequences of a spontaneous order [such as a market] which have not been deliberately brought about by anybody."

I think that Hayek is mistaken about this and that he exaggerates the implications of Rawls's refusal to consider the justice of particular allocations of goods. Rawls's position may be illuminated as follows: Suppose that, on one occasion, the institutions of our economy happen to yield a distribution of wealth, $D_{1}$, that is judged inferior in terms of the Difference Principle to another distribution, $D_{2}$. Should we immediately interfere and reallocate wealth so that we change $D_{1}$ into $D_{2}$ ? Rawls's answer, like Hayek's, is "no." For Hayek the matter ends there. But for Rawls there is a further question to be addressed: can we change the institutional structure so as to render it more likely in the future that the normal operation of our economy will yield distributions like $D_{2}$ rather than $D_{1}$ ? The answer to this may also be "no" because the proposed change might be incompatible with institutional virtues such as publicity, stability, and the rule of law. ${ }^{49}$ The new institutions that are being suggested may not, as it were, hold up as institutions. Still—and this is what Hayek overlooks - the answer is not necessarily "no." If change is possible and if the resulting institutional structure would be viable, stable, et cetera, then we are required as a matter of justice to implement it for the Difference Principle just is the requirement that we arrange - and, if necessary, rearrange-our institutions so that social and economic inequalities are to the greatest benefit of the least advantaged. So, for example, if we find ourselves in a market society that lacks basic welfare provision, we have to consider whether the institutional structure of a market economy would be wrecked qua institutional structure by the addition of what Rawls calls a "transfer branch" charged with administering a social minimum. ${ }^{50}$ Would that make it impossible for the economic structure as a whole to operate predictably, publicly, impersonally, and

46. 2 F.A. Hayek, Law, Legislation and Liberty: The Mirage of Social JUSTICE xiii (1976).

47. Id. at 100,183 n.44.

48. Id. at 38, 166 n.19.

49. RAWLS, supra note 4, at 48-49, 206-13.

50. Id. at 244-45. 
in accordance with other institutional virtues? Hayek has devoted a large part of his life to arguing that it would: that the modern regulated welfare state is incompatible with the rule of law. ${ }^{51}$ It is pretty clear that Rawls disagrees with him about that. ${ }^{52}$ But the deeper disagreement is that Rawls thinks it is the job of a theory of justice to select principles for evaluating economic institutions along exactly these lines, whereas Hayek simply denies that that is a legitimate concern about justice.

I have taken this digression into the Hayek-Rawls misunderstanding because I want to stress again that in a theory of justice like Rawls's, we cannot guarantee that socioeconomic rights will emerge in a familiar or predictable form. As an abstract matter we can say, with the drafters of Article 25 of the UDHR, that everyone has "the right to a standard of living adequate for the health and well-being of himself and his family." ${ }^{3}$ But that may not necessarily emerge as a specific legal or constitutional guarantee: a just society may not have a rule to that effect or even any particular agency charged with administering this standard. There may be a variety of provisions and arrangements, ranging from tax breaks to educational opportunities to rent control to unemployment insurance schemes, all of which taken together may represent the bestand genuinely the best - that can be done in an institutional framework to honor the underlying claim for the individuals in whose behalf it can be made.

\section{CONTRACTARIAN ARGUMENTS FOR PRINCIPLES OF JUSTICE}

I said at the beginning of this Article that it is not devoted specifically to John Rawls's theory of justice or to the implications of that particular theory for socioeconomic rights. Still, Rawls's theory is a good paradigm to work with, and it has contributed to the study of justice a number of ideas that have more general application. One of them is the contractarian idea of the original position: the idea that it might be fruitful to approach questions of justice by imagining people making decisions about important structural aspects of their society or about important political and legal principles that they were to be committed to

51. See Friedrich A. HayeK, The RoAd to Serfdom 72-73 (1944); F.A. HayeK, THE CONSTITUTION OF LIBERTY 205-06 (1960).

52. Otherwise he would not take it for granted that a just basic structure will have a transfer branch that "guarantees a certain level of well-being and honors the claims of need.” RAWLS, supra note 4, at 244.

53. G.A. Res. 217 (III) A, supra note 1, at 76. 
from behind a veil of ignorance, in which they prescinded from all knowledge of their own particulars that might give them an idea of how such arrangements would impact on their own well-being. ${ }^{54}$ So, for example, people might be required to imagine considering arrangements about racial discrimination without knowing what race they belonged to or arrangements about the state's relation to religion without knowing what religion they belonged to.

Would it be appropriate to approach the principles underlying socioeconomic rights from this perspective? Could one argue, for example, that principles roughly similar to those that I mentioned at the beginning of this Article-the principles of socioeconomic rights that one finds in the UDHR, the ICESCR, or the South African Constitution-might emerge from a contractarian theory as the upshot of asking what people would agree to from behind the Rawlsian veil of ignorance?

In light of what was said in Part IV, one might imagine a Rawlsian response to the effect that a nonallocative theory simply does not generate principles of that sort in this direct way. Rawls might say that if justice requires welfare payments, for example, then that will emerge in the course of the detailed elaboration of what is implied as a matter of public policy by the very abstract propositions that are the subject matter of decision in the original position. (We will examine this in Part VIII.) But, he will say, it misconstrues the order of argument in Rawls's conception to think that welfare can emerge as a matter of right as a result of directly applying the idea of choice behind the veil of ignorance.

But actually that is not quite right, at least as far as Rawls's own theory is concerned. The "First Principle" of Rawls's conception of justice as fairness contains what he refers to as "equal basic liberties," under which heading we find many principles that are regarded as human rights. ${ }^{55}$ These include political liberties, freedom of speech and assembly, liberty of conscience and freedom of thought, freedom of the person, and freedom from arbitrary arrest. ${ }^{56}$ According to Rawls, these are argued for directly using the idea of the original position. ${ }^{57}$ For example, the argument for the right of freedom of conscience is that "persons in the original position.... cannot take chances with their liberty by permitting the dominant religious or moral doctrine to

54. For other uses of contractarian or quasi-contractarian approaches, see BRUCE A. Ackerman, Social Justice in the Liberal State 327-28 (1980), and T.M. SCANLON, WHAT We OWE TO EACH OTHER 189-90 (1998).

55. RAWLS, supra note 4, at 53.

56. Id.

57. Id. at 181 . 
persecute or suppress others if it wishes." ${ }^{58}$ So we might ask, If this is an appropriate way of arguing for rights of religious liberty, why would it not also be an appropriate way of arguing for other rights such as socioeconomic rights?

One contrast between a theory of justice and a theory of rights is that although the latter is often just presented as a list without addressing issues of conflict and priority, the former aspires to a more unified and systematic account. But in fact, Rawls's theory of justice turns out to have some list-like aspects too. "[I]t is essential," he says, "to observe that the basic liberties are given by a list of such liberties."59 This might encourage us to think that we could just insert a list of social and economic rights in our theory of justice, as Rawls inserted a list of civil and political rights in his First Principle. In a later discussion, Rawls says:

Some may think that to specify the basic liberties by a list is a makeshift which a philosophical conception of justice should do without. We are accustomed to moral doctrines presented in the form of general definitions and comprehensive first principles. Note, however, that if we can find a list of liberties which ... leads the parties in the original position to agree to these principles rather than to the other principles of justice available to them, then what we may call "the initial aim" of justice as fairness is achieved. This aim is to show that the two principles of justice provide a better understanding of the claims of freedom and equality in a democratic society than the first principles associated with the traditional doctrines of utilitarianism. ${ }^{60}$

He goes on to say that, for this purpose, the list can be drawn up by considering "which liberties are essential social conditions for the adequate development and full exercise ... of moral personality over a complete life," and we bring that together with a survey of "the constitutions of democratic states," particularly those that have worked well, to see which of these liberties are normally protected. ${ }^{61}$ We might try out various lists, moving back and forth between the criteria just mentioned and a sense of what would be accepted in the original position, until we have come up with a "last preferred list."62

Well, then, we might say that there is no reason why such a methodology should not take us beyond traditional civil and political rights into the realm of socioeconomic rights. Prominent international

58. Id.

59. Id. at 53

60. John RaWls, Political Liberalism 292 (1996).

61. Id. at 292-93.

62. Id. at 293. 
human rights instruments now include these as do certain wellfunctioning constitutions, such as that of South Africa. Those who believe in such rights defend them by arguing that they indeed represent "essential social conditions for the adequate development and full exercise ... of moral personality."63 And as we shall see in a moment, there might well be a direct original-position argument to be made in their favor. If all this is true, then the list-ness of socioeconomic rights - the fact that they are not theorized in the way that theories of justice normally theorize things - need not be an obstacle, at least if we accept the general outlines of Rawls's methodology in this regard and buy into his rejection of the criticism-which is more or less a version of the criticism with which I began this Part - that the use of such a list of rights in a theory of justice is a disreputable "makeshift."

All that is quite persuasive. On the other hand, there may possibly be reasons specifically for not treating socioeconomic rights in this manner, which do not apply straightforwardly to the civil and political liberties on Rawls's list. Consider, for example, Rawls's reasons for not including the fair value of liberty-the material resources that enable one to use one's liberties to one's advantage- under the heading of the First Principle. Rawls writes:

The inability to take advantage of one's rights and opportunities as a result of poverty and ignorance, and a lack of means generally, is sometimes counted among the constraints definitive of liberty. I shall not, however, say this, but rather I shall think of these things as affecting the worth of liberty. ${ }^{64}$

The point of this distinction is not to heartlessly brush aside questions about poverty and lack of means. Rawls did not believe that a society could pride itself on offering its poorer citizens civil and political rights, in this narrow sense, without paying any attention to their material condition. But it is precisely the task of the "Second Principle" governing social and economic inequalities to pay attention to this matter. The connection between a liberty and the worth of that liberty binds the two principles of justice together by indicating the importance of economic well-being in determining whether the liberties governed by the First Principle are actually worth having. But if the worth of liberty had to be dealt with under the First Principle, there would be precious little for the Second Principle to deal with because almost all of the primary goods affected by the Second Principle have some direct or indirect relevance to the effective use that one can make of the rights governed by the First Principle.

63. Id.

64. RAWLS, supra note 4 , at 179. 
In general, it is arguable that the civil and political liberties on Rawls's list can be dealt with qua rights separately from the other concerns of a theory of justice. In and of themselves, the civil and political liberties do not have massive implications for the issues of social and economic distribution that Rawls's other principle addresses. ${ }^{65}$ (I do not mean that civil and political rights have no resource implications at all; I mean that their resource implications are patchy, sporadic, and often indirect.) Socioeconomic rights, on the other hand, have very substantial implications, both for the resources that Rawls's Second Principle is likely to govern and for the basis of our overall assessment of the impact of the basic structure on people's life prospects. This means, first, that if socioeconomic rights were included in the First Principle, then the First Principle would do much of the work supposedly allocated to the Second Principle. ${ }^{66}$ And it means, second, that if socioeconomic rights were inserted in this fashion anywhere in Rawls's theory-not necessarily under the auspices of the First Principle-then it would turn out to be the case that a very substantial part of the work of the theory would consist simply in a list of rights, and its systematic theoretical character would be largely lost. One gets the impression that some if not most of the conclusions of Rawls's theory are supposed to be presented as derivations from "general definitions and comprehensive first principles," even if the list of basic liberties is not. ${ }^{67}$ But if socioeconomic rights are articulated in the way we have been imagining, then it will be the case that the whole theory begins to look makeshift, not just a part of it.

All of this leaves open the possibility, however, that when it comes to the elaboration and defense of his Second Principle, Rawls might be constrained by the original-position method to include fundamental constraints that require attention to the issue of poverty and deprivation. After all, the Second Principle is itself complex: it conjoins the Difference Principle with a Principle of Equal Opportunity that constrains its

65. See Stephen Holmes \& Cass R. Sunstein, The Cost of Rights 115-16 (1999); HENRY SHUE, BASIC RIGHTS 75-76 (1980).

66. H.L.A. Hart, Rawls on Liberty and Its Priority, in READING Rawls 230, 23637 (Norman Daniels ed., 1989) made an analogous criticism of Rawls's early suggestion that the First Principle governed the distribution of liberty in general, not just specific basic liberties. Because all resource allocation involves the allocation of liberty via the right to use and the right to exclude, such an agenda would cover the whole domain of resource use.

67. RAWLS, supra note 60, at 292. 
operation, and it is not unimaginable that we might say that one or both of these are also constrained by something like socioeconomic rights. ${ }^{68}$

Would persons in the original position insist on such constraints? The answer is "possibly, yes"-in fact, the claim that they would insist on some such constraint might be more plausible than the claim that they would adopt the Difference Principle as that is ordinarily understood. Let me explain. Rawls's own view is that any individual behind the veil of ignorance choosing principles to govern the basic structure of society in which the individual was to live would insist on a principle that ensured social and economic inequalities were regulated to the advantage, in the first instance, of the least well-off group. ${ }^{69}$ This is the Rawlsian Difference Principle. (As we have seen, that principle is not itself supposed to determine what anyone is entitled to, but it would not be surprising if it commanded the institution of something like a modern system of tax and transfer.) Many critics, however, find it incredible that people in the original position would be so solicitous of the worstoff group in all circumstances. ${ }^{70}$ They concede that such solicitude might be intelligible on the assumption that members of the worst-off group are suffering serious deprivation. But if everyone is enjoying great luxury, it seems odd to commit oneself to a principle that we must always pay attention to plight of members of the group enjoying the least luxury, sacrificing if necessary the possibility of more luxury overall. This suggests that the reasons for parties in the original position to choose something like the Difference Principle evaporate as the actual level of well-being of the worst-off group improves. Of course, the parties behind the veil of ignorance are assumed not to know what the level of general prosperity is, but they might adopt a conditional principle. They might say, "If the worst-off group is below a certain (specified) absolute level of deprivation, then all social and economic inequalities should be oriented to their advantage; if they are above that level of deprivation, then that exclusive concern may not be appropriate." In other words, individuals choosing from behind the veil of ignorance might explicitly adopt some principle of social minimum. ${ }^{71}$ They might reason, for example, that they should make all efforts to avoid radical deprivation of a sort that might undermine the most important aspects of human functioning: the nutrition necessary for ordinary action and reproduction, the shelter and clothing necessary for

\footnotetext{
68. Id. at $53-55$.

69. Id. at $130-60$.

70. Id. at 68; see also AdAm Swift, Political Philosophy 26-27 (2d ed. 2006).

71. A principle oriented to the social minimum would be different from the social minimum policy discussed by Rawls. See RAWLS, supra note 4, at 244-45, 251-52; see also JOHN RAWLS, JUSTICE AS FAIRNESS 127-29 (Erin Kelly ed., 2001).
} 
life, and so on. They might figure that serious limitations on the upside prospects of social arrangements would be justified for the sake of avoiding these desperate possibilities. If this was their approach, then they would, in effect, have adopted something very similar to what we call socioeconomic rights - rights calculated to ensure that those in a society who are materially radically disadvantaged are, if possible, raised by collective provision above the level of radical disadvantage. ${ }^{72}$

It seems to me that this is the most promising avenue for the generation of something like a fundamental right to welfare provision. But it is worth noting that given the level at which it emerges in, say, a neo-Rawlsian theory of justice, there is much more work to be done before we can conclude that such a theory requires that people in a wellordered society actually be vested with such a right. (I will discuss this further in Part VIII.)

\section{CHOICE AND PERSONAL RESPONSIBILITY}

Many of those who would benefit if socioeconomic rights were recognized are destitute and in need of the assistance that these rights afford through no fault of their own. Others, however, are destitute because of bad choices they have made. Some are in need because of sheer bad luck that has nothing to do with choices they made; others are in need because they chose to take, and hoped to benefit from, a risk that had penury as one of its possible outcomes. Again, some are in need of the help that such rights require because neither they nor their parents nor their grandparents ever had access to anything remotely like a fair share of their society's - or the world's - wealth or a fair opportunity to make a decent and self-sufficient life for themselves. But this is not true of everyone, for some may have squandered a fair share and need assistance now on account of their own lack of prudence.

It is possible to defend socioeconomic rights in a way that makes distinctions like these irrelevant at a certain level of compelling need. A starving person is a starving person, we might say, and they have a right to our help even when they are responsible for their predicament or even

72. Elsewhere I have argued that this position is also supported by what Rawls says about the impact of "strains of commitment" on reasoning in the original position. See Jeremy Waldron, John Rawls and the Social Minimum, 3 J. Applied PhIL. 21, 21 (1986), reprinted in JEREMY WALDRON, LiBERAL RightS: COLlECTED PAPERS 19811991, at 250, 250 (1993). 
when they have previously been given a fair share as far as the requirements of distributive justice are concerned. However, it is widely believed - certainly as a matter of pretheoretic considered judgmentthat these distinctions are not altogether irrelevant for a theory of justice. It is possible, I guess, that a theory of justice might repudiate these distinctions altogether. Sometimes Rawls gives that impression in his comments about desert. ${ }^{73}$ And neither the argument for the Difference Principle nor the Rawlsian social minimum argument I outlined in the previous Part seems to pay any attention to the question of individuals' own responsibilities for their membership in the worst-off group. ${ }^{74}$ Still, we might insist, a theory of justice is inadequate if it says nothing to address this question or allay the concerns that it raises. Even if it is believed that choice and responsibility should not matter at the extremity of need, still some account must be given of the intuitions that underlie these concerns about choice and responsibility and of why these intuitions do not always have the importance that their proponents say they have.

Some theories of justice have made these distinctions fundamental. In Ronald Dworkin's account of equality of resources, for example, we are to think in terms of a model in which each person is assigned an equal share of resources-configured by processes that treat the person as an equal in determining how things should be divided or how nonfungible items should be treated. $^{75}$ But once resources are assigned, we assume that holdings will quickly become unequal as a result of various processes:

Some may be more skillful than others at producing what others want and will trade to get. Some may like to work, or to work in a way that will produce more to trade, while others like not to work or prefer to work at what will bring them less. Some will stay healthy while others fall sick, or lightning will strike the farms of others but avoid theirs. For any of these and dozens of other reasons some people will prefer the bundle others have in say, five years, to their own. ${ }^{76}$

Some of the hardest work required by Dworkin's model then involves distinguishing, among these various ways in which people's holdings might become unequal, those that represent the results of fair choicesinvestments, gambles, preferences for leisure over work-and those that represent brute bad luck. It has always been Dworkin's position that one does not treat people as equals if one requires that they be insulated from the consequences of their own free choices. People who worked or saved in order that they would have enough resources for a rainy day are

73. RAWLS, supra note 4, at 273-77.

74. See, e.g., Ronald DwOrkin, Is Democracy Possible Here? 103-04 (2006).

75. Ronald Dworkin, What Is Equality? Part 2: Equality of Resources, 10 PHIL. \& PuB. AfF. 283 (1981).

76. Id. at 293-94. 
not treated with equal dignity if they are required to subsidize people who did not work or save, despite being conscious of what the consequences of that would be and despite having had the opportunity to do so. As Dworkin puts it in his most recent book, ideals of equality and justice must treat us as having in the first instance a responsibility to determine by our own choices how our lives should go. ${ }^{77}$ But opportunities for work or savings may not have been equal; people may be handicapped or struck by illness, and in these instances a plausible case can be made for social assistance that does not involve an affront to the dignity of personal responsibility. What the extent of that assistance should be is determined in Dworkin's model by imagining various markets, actual and hypothetical, for insurance. People who begin with equal holdings are imagined also to have had a fair and equal opportunity to insure against bad luck, such as illness or unemployment. If such insurance opportunities are not available-again through no fault of their own - then they are said to be entitled to the assistance that they would have received in a fair insurance market had such a market existed. The details of this account need not detain us here. What is important to understand is that these model-theoretic assumptions-an equal initial assignment of resources, responsibility for chosen outcomes even when these are unequal, and the provision of either an equal opportunity to insure against brute bad luck or the payouts that a fair insurance market would have provided-work in the infrastructure of the theory to provide perspectives for thinking about the actual hazards and inequalities of the real world. Dworkin is not arguing for the setting up of any particular social insurance mechanisms as a matter of policy; instead he is using these devices as a way of thinking through the tangled issues about choice, luck, and responsibility that he believes are unavoidable in a theory of justice.

Dworkin's is just one theory; there are other theories of justice that engage in similar analysis. And there are some-like Rawls's theory, as we have seen-that give these issues much less prominence. It may seem that a proponent of socioeconomic rights-someone who takes seriously Article 11(1) of the ICESCR: "[T] he right of everyone to an adequate standard of living for himself and his family" — — should always favor theories of the latter kind over theories of the former kind. But

77. See RonAld DwORKIn, Justice FOR HEdGEHOGs 330 (2011).

78. G.A. Res. 2200 (XXI) A, supra note 2, at 50. 
quite apart from general difficulties of derivation, that assumes that we already know what socioeconomic rights are justified; it assumes we have already chosen between, say, the conditional formulations in UDHR Article 25(1) ${ }^{79}$ and the unconditional formulation from ICESCR just quoted. One is entitled to ask, How can we know that without having considered what is to be said in favor of a theory of justice of the Dworkinian kind as against a theory of justice of the Rawlsian or neoRawlsian kind? We cannot just "intuit" it because, as we saw in Part II, our intuitions on this are all over place. There is no substitute for doing the hard work that theorizing about justice requires, and that involves thinking through what might actually justify taking sides in the RawlsDworkin dispute.

\section{SECOND-BEST THEORY}

In actual fact, no one has been assigned an initially equal share of resources, nor have most people had an opportunity to insure themselves in a fair market against lack of talent, disability, or various forms of bad luck. They are stuck in the real world, cursed with a heritage of what almost anyone would have to describe as injustice, and that is the world in which they suffer unemployment, deprivation, and insecurity, in which their children go hungry, and in which they have to make whatever appalling choices are left open to them. Rawls's theory is similarly unrealistic. None of us was put in an original position and asked what principles we would choose to put up with or what principles we would be able to put up with to govern the basic structure of our society. To the extent it is governed by principles at all, the basic structure of our society is governed by principles manifestly rigged to the advantage of some and the detriment of others. Or even when it is governed by fair principles, we play the game that those principles define-such as the market game-with radically disparate initial endowments of property and other resources. Even Nozick acknowledges the prominence of injustice in the real world. No one thinks that current holdings of property are respectable by the historical standards that he articulates. The pedigrees of all our holdings are contaminated with the cruelest injustice, and when wealthy individuals are being required to support the meager lifestyle of people much less fortunate than them, it is quite unclear whether they are being required to do so out of

79. G.A. Res. 217 (III) A, supra note 1, at 76 ("Everyone has the right to a standard of living adequate for the health and well-being of himself and of his family, including food, clothing, housing and medical care and necessary social services, and the right to security in the event of unemployment, sickness, disability, widowhood, old age or other lack of livelihood in circumstances beyond his control.” (emphasis added)). 
resources that are morally theirs or out of ill-gotten resources that are "theirs" only in the shallowest of legal senses.

In general, theories of justice do not seem to be designed for the real world. But the socioeconomic rights that people talk about are. They are designed exactly to operate in a real world that does not answer to ideal models of the philosophers. "[T]he right of everyone to an adequate standard of living for himself and his family" laid down in Article 11(1) of the ICESCR is supposed to apply in real world situations, whether or not those situations are properly governed by the strictures of whatever turns out to be the best theory of justice. ${ }^{80}$ True, accounts of socioeconomic rights are sometimes accused of being utopian. (We considered this above in Part III.) But assuming that what these rights require can be done, the position of their proponents is that it ought to be done without further ado, and certainly without waiting for the rest of an ideal theory of justice to swing cumbersomely into application.

On the other hand, the thought that socioeconomic rights ought to have this immediate real-world application does not mean that they can be considered entirely apart from theories of justice. Most theorists of justice defend their emphasis on ideal theory because they think it illuminates and provides the best basis for approaching issues of nonideal theory. Rawls is typical:

\begin{abstract}
I examine the principles of justice that would regulate a well-ordered society. Everyone is presumed to act justly and to do his part in upholding just institutions.... Thus I consider primarily what I call strict compliance as opposed to partial compliance theory. The latter studies the principles that govern how we are to deal with injustice.... Obviously the problems of partial compliance theory are the pressing and urgent matters. These are the things that we are faced with in everyday life. The reason for beginning with ideal theory is that it provides, I believe, the only basis for the systematic grasp of these more pressing problems.... At least, I shall assume that a deeper understanding can be gained in no other way. ${ }^{81}$
\end{abstract}

The need for a "systematic grasp" is important. The disordered world in front of us is certainly the product of injustice. But which aspects of the disorder that we see are to be attributed to injustice? If the existing situation is unjust, then something needs to be done about it. But what? And are we sure we can distinguish intuitively and without theoretical

80. G.A. Res. 2200 (XXI) A, supra note 2, at 50.

81. RAWLS, supra note 4, at 7-8 (citations omitted). But see Amartya SEN, The IDEA OF JUSTICE vii-xii (2009), for a more aggressive insistence on focusing on perceptions of injustice in the first instance. 
consideration what would ameliorate and what would aggravate an unjust situation? I do not mean that we must simply sit on our hands until the theorists of justice laboriously get around to considering second-best theory. But it is not clear how it is safe to proceed without someone doing some second-best theory-if only to be sure that the rights we propose to enforce actually do a good job of capturing what justice requires in this fraught and terrible situation.

In this regard, Robert Nozick's comments about injustice in the real world are particularly interesting. Nozick was never prepared to say that the historical-entitlement critique of equality and welfarism in Anarchy, State, and Utopia amounted to a defense of actually existing market institutions, nor would he pretend that the sort of Lockean defense of property he advocated could go any distance towards legitimizing contemporary disparities of wealth in, for example, the United States. On the contrary, he thought it undeniable that contemporary holdings would be condemned as unjust by any remotely plausible conception of historical entitlement. (The point of Nozick's argument in chapters 7 and 8 of Anarchy, State, and Utopia was that egalitarians were condemning the existing distribution for the wrong reason-simply as unequal-rather than on account of the violence, fraud, expropriation, ethnic cleansing, and state corruption involved in the history of most holdings of property in America.) He acknowledged that once actual historical injustice was established, the burden would fall on the part of his conception dealing with the rectification of injustice. The ideal part of Nozick's theory might reject welfare transfers out of hand as violations of property owner's rights; it might condemn income taxes as amounting to illicit and coercive seizure of labor from honest workers. But he doubted whether these condemnations could be sustained once one started figuring out how to deal with the burden of actual injustice:

\footnotetext{
These issues are very complex and are best left to a full treatment of the principle of rectification. In the absence of such a treatment applied to a particular society, one cannot use the analysis and theory presented here to condemn any particular scheme of transfer payments, unless it is clear that no considerations of rectification of injustice could apply to justify it. ${ }^{82}$
}

That itself is a remarkable and honest concession. But if we accept it, we also have to accept the corollary that the schemes of transfer that seem most obvious to us - as proponents of socioeconomic rights-may not be exactly (or even approximately) the schemes of transfer that rectification requires. It may not be easy to say what rectification requires, but it is worth considering at the very least whether there are

82. NozICK, supra note 10, at 231. 
any important pitfalls and oversimplifications that it requires us to steer clear of.

\section{JUSTICE AND PUBLIC POLICY}

In Rawls's theory and in other theories of justice, there is considerable distance between the models that the theory uses and the principles that it generates, on the one hand, and particular policy recommendations, on the other. ${ }^{83}$ (This is as true of nonideal theory as of ideal theory. There is likely to be considerable distance between the theory of what Rawls calls partial-compliance or the theory of what Nozick calls rectification, on the one hand, and particular policy recommendations, on the other.) How is this distance to be navigated? There are two ways of answering. One is to consider the substantive reasoning that is involved in using principles of justice to generate public policy recommendations. The other is to consider the institutional processes by which this reasoning is actually conducted.

Substantively, we should try to ensure that the route taken from abstract principles to particular policy recommendations passes through a consideration of the way in which the laws and institutions impacting people operate as a whole. We know that what we do about health care, for example, may affect employment opportunities, or the quality and fairness of the provision that is made for public education may determine how badly the impoverishment of certain families affects the prospects and opportunities for children. I think John Rawls is right to insist that the subject of justice is the basic structure of society taken as a whole and considered in respect of the impact it has as a system on the life prospects of each individual. ${ }^{84}$ Socioeconomic rights, as commonly formulated, do not take this perspective. Instead they deal, in what I have said is a sort of line-item way, with particular areas of public policy - with education, social security, health care, provision for the very poor, and so on-each area with its right or set of rights. A list of socioeconomic rights does not have the capacity that a theory of justice has to consider and evaluate the net impact that the basic structure

83. There may also be some distance between socioeconomic rights-formulated as human rights or constitutional rights - and social policy recommendations: an actual system of welfare provision, however generous, is much more than just a positivization of propositions like Article 25(1) of the UDHR or Article 11(1) of the ICESCR. But the distance is likely to be much less in this case.

84. RAWLS, supra note 4 , at 6-10. 
comprising all of these aspects taken together will have on the life prospects of various individuals.

Of course specific public policy prescriptions will focus on particular topics; they will not themselves be holistic. And claims of socioeconomic rights are like them in this regard. So we may say that the socioeconomic rights represent-or are very close to-policy outputs, and that a mistake has been made in this Article by comparing them to principles of justice that are not identifiable with output prescriptions in the same way. That is fair as far as it goes. The trouble is that claims of right often present themselves not just as specific policy demands but as each sitting on its own bottom, so to speak, with its own separate foundations. Rights present themselves as separable in their formulation and in their foundations. Just as the principle of free speech is justified in a way that is quite separate from, say, the right not to be tortured, the idea is that Article 11 of the ICESCR will have its own justification, Article 12 will have a somewhat different justification, and so on. Each right stands on its own and demands attention. In that regard, rights differ quite radically from the policy prescriptions that emerge from the application of a theory of justice like Rawls's theory. Superficially they may resemble one another. But what the Rawlsian theory generates regarding what is required in the way of, say, education will emerge from a process in which both the competition between education and other demands on resources and the relation between education and other arrangements' impact on people's life prospects have been properly considered together. That is unlikely to be true of the socioeconomic rights.

Let me emphasize that I do not rule out the possibility that some claims that are both particular and more or less absolute may emerge from a theory of justice. (We considered this in Part V.) Maybe elementary education, for example, is so important in and of itself to children's life prospects that even taking into account other impacts and other demands that compete for the same resources, it must emerge in its own right as an uncompromising demand. That is certainly a possibility and-I am saying - that is the way to establish that there are socioeconomic rights. Just consulting a list is not.

Turning now to the institutional context, we might note that one advantage of working through these issues in the context of a theory of justice is that it postpones as long as possible commitment to any particular political or institutional process. Introducing the language of rights tends to tilt matters decisively towards judicial rather than legislative or executive processes. In many political systems, rights are entrusted as a matter of course to courts for administration or enforcement. It is true that sometimes legislation may be devoted to a scheme for the implementation of people's rights: one thinks of the Civil Rights Acts in 
the United States, for example. In general, however, it is commonly thought to be the task of the courts to determine finally whether a legislative scheme properly respects people's rights and whether particular legislation unduly encroaches on or neglects or undermines people's rights. ${ }^{85}$

This makes a certain amount of sense in the case of ordinary civil and political rights. Though there are issues of interpretation, the rights themselves are generally self-contained, and any issues of conflicts between rights are of a sufficiently modest character to be dealt with case by case using some sort of balancing test. In the case of socioeconomic rights, however, we are dealing with entitlements each of which represents a claim to a share of arguably scarce resources. Moreover, these resources are made available under the auspices of the state budgets, where various welfare claims compete with one another and with other demands for funding, not to mention the fact that their availability in the first place depends on taxation, which means that, in some sense, they compete with other personal as well as fiscal priorities that taxpayers may have. Socioeconomic-rights claims in court are not just interpretive, as other rights claims are; they are also inherently budgetary - they have very extensive fiscal implications. It is far from clear that a courtroom is the right place for such claims to be resolved; many have argued that it is not. ${ }^{86}$ On the other hand, some judges and legal scholars have come up with sophisticated and imaginative ways in which courts can vindicate claims of this kind without encroaching too far into the fiscal responsibilities of the elective branches of government. ${ }^{87}$ Even so, it would be a pity if courts came to be seen as the main way or the only way to vindicate these claims. If we assume that it is important for them

85. Elsewhere I have criticized the practice of rights-based judicial review of legislation, but I do not propose to take up that general issue here. See Jeremy Waldron, The Core of the Case Against Judicial Review, 115 YALE L.J. 1346 (2006).

86. See, e.g., Aryeh Neier, Social and Economic Rights: A Critique, 13 Hum. RIGHTS BRIEF 1, 2 (2006) ("[W]henever you get to these broad assertions of shelter or housing or other economic resources, the question becomes: What shelter, employment, security, or level of education and health care is the person entitled to? It is only possible to deal with this question through the process of negotiation and compromise. Not everybody can have everything. There have to be certain decisions and choices that are made when one comes to the question of benefits, and a court is not the place where it is possible to engage in that sort of negotiation and compromise.”).

87. The work of the South African Constitutional Court has been exemplary in this regard. See, e.g., Minister of Health v. Treatment Action Campaign 2002 (10) BCLR 1033 (CC) (S. Afr.); Gov't of the Republic of South Africa v. Grootboom 2000 (11) BCLR 1169 (CC) (S. Afr.); see also Mark Tushnet, Social Welfare Rights and the Forms of Judicial Review, 82 TeX. L. REV. 1895, 1895-97 (2004). 
to be pursued also in a political context, then the justification for elaborating socioeconomic claims in the context of a theory of justice is evident. Theories of justice offer us principled ways of thinking about rival demands in politics that take seriously their individualized distributive dimension while at the same time not flinching from the fact that they do compete with other demands. Introducing rights formulations at an early stage prevents this, or makes it more difficult, or makes its success depend precariously on complex and sophisticated structures dealing with possible conflicts of rights that, as things stand, many modern theories of human rights lack.

\section{CONCLUSION}

It is an unhappy feature of the language of rights that it expresses demanding moral claims in a sort of line-item way, presenting each individual's case peremptorily, as though it brooked no denial, no balancing, and no compromise. That feature of rights has always troubled those who are sensitive to the fact that individuals live in a social environment where the things that they may reasonably expect must be adjusted constantly to reflect similar expectations on the part of others. The language of absolute and uncompromisable demands is simply inapt to capture anything important about our moral situation in such an environment. I think this applies as well to socioeconomic rights as to other rights claims. It may be said that there is no difference in this regard between theories of rights and theories of justice, for the latter can be uncompromising also: Fiat justitia ruat caelum. But in fact they are not on par. A general theory of justice purports to take into account urgent claims of all kinds-including whatever claims there are about the wrongness or desirability of the sky's falling. It generates its conclusions on the basis of such consideration. Theories of rights generally do not; their formulations may, to a certain extent, reflect constraints of equality and universalizability, but all too often this dimension of argument about rights is rudimentary, and sophisticated argument about conflicts of rights is nonexistent.

It seems best, therefore, to postpone talking about socioeconomic rights until we have considered how various socioeconomic claims fare in a theory of justice. I do not mean to deny that some claims of the sort that we find in Articles 9-13 of the ICESCR or in Articles 23-26 of the UDHR may turn out to be justified. The point is that a stronger and more compelling case can be made for them if they are validated within the context of theorizing that enables other claims, other demands, and other moral considerations to make their best pitch against them. Theorizing about justice offers just such a context. So for that reason, I 
think it is better to let socioeconomic rights emerge from a theory of justice than to try to defend them, line by line, on their own merits. 
